\title{
Students' Knowledge about Sex and HIVIAIDS: The Case of Agona District in the Central Region of Ghana
}

\author{
Hordzi, W. H. K. \\ Institute for Educational Development And Extension \\ University of Education, Winneba, Ghana \\ wisdomhordzi@yahoo.com
}

\begin{abstract}
Two hundred and twenty two (222) students in Junior and Senior Secondary Schools were sampled in the Agona District in the Central Region of Ghana to find out the extent of their sexual activity and their awareness on HIV/AIDS. The results show that the students were sexually active and some of them started at the early stage of 8 years. The boys were more sexually active than the girls. However, a large number of those of them engaged in sex $(76.66 \%)$ did not use the condom. Though $63.05 \%$ of respondents knew that HIV/AIDS is caused by a virus (a germ) some others believe that HIV/AIDS is as a result of curse or punishment from God or gods and only offenders contract the disease. Despite the fact that most of the respondents had good knowledge of the modes of spread, symptoms, preventive measures and ways of living with people living with HIV/AIDS (PLWHA) a large number of them also had different kinds of misconceptions. The differences between the total frequencies were very highly significant $\left(\mathrm{X}^{2}=44.77, \mathrm{P}<0.001\right)$. All the respondents indicated that it is wrong to use the same blade with PLWHA. The differences between the total frequencies were very highly significant $\left(\mathrm{X}^{2}=57.01, \mathrm{P}<0.001\right)$
\end{abstract}

Key words: acquired immune deficiency syndrome, opportunistic, transfusion

\section{Introduction}

Acquired Immune Deficiency Syndrome (AIDS) was first reported in the United States of America (USA) in 1981 and has since become a major worldwide epidemic (Office of Communications and Public Liaison (O.C.P.L) (2003). The germ that causes AIDS is called Human Immunodeficiency Virus (HIV). O.C.P.L (2003) observed that HIV, the AIDS virus kills or damages cells of the body's immune system and progressively destroys the body's ability to fight infections and cancers. HIV is most commonly spread by having unprotected sex with infected partner. The Virus can enter the body through the linings of the vagina, vulva, penis, rectum or mouth.

HIV can also be spread through infected blood. The virus is also spread among injection drug pushers through sharing of needles or syringes contaminated with very small quantities of blood from an infected person. Women can also transmit HIV to their babies during pregnancy or birth. Approximately one quarter to one third of all untreated pregnant women infected with HIV will pass the infection to their babies (O. C. P. L, 2003). Office of Communications and Public Liaison (O.C.P.L) further stated that the virus can also be spread to babies through breast milk of infected mothers. However, if the mother takes the drug AZT during pregnancy, she can significantly reduce the chances that her baby will be infected with HIV. Having sexually transmitted diseases such as syphilis, genital herpes, chlamydeous 
infection, gonorrhoea, or bacterial vaginosis makes people more susceptible to getting HIV infection during sex with infected person (O. C. P. L, 2003).

The HIV virus causes decline in the number of CD4 Positive T cell (also called T 4 cells) found in the blood - the immune system's key infection fighters (Alhassan, 2001). As the immune system weakens, a variety of complications start to take over. Office of Communications and Public Liaison (2003) observed that the most advanced stage of HIV is AIDS. That is the stage of numerous opportunistic infections that generally do not affect healthy people. They claimed that, in some people these infections become so severe and fatal because their immune system is so damaged by HIV that the body cannot fight certain bacteria, viruses, fungi, parasites and other microbes.

According to O.C.P.L. (2003), though there is not yet any cures for HIV/AIDs, there are drugs, which cure the opportunistic diseases and cancers. Though such drugs do not cure AIDS, they greatly improve the health of many people with AIDS and thus reduce the amount of virus circulating in the blood to nearly undetectable levels among HIV/AIDS patients in the developed countries. However, it was found out that HIV remains present in hiding places such as the lymph nodes, brain, testes, and retina of the eye (O.C.P.L. 2003),

Since there is not yet any cure or vaccine against HIV/AIDS, the disease is continuously spreading across the world. According to UNAIDS (2002), as at the end of 2002 an estimated 42 million people world wide -38.6 million adults and 3.2 million children younger than 15 years were living with HIV/ AIDS. Approximately $70 \%$ of these people (29.4 million) live in Sub-Saharan Africa. Another 17\% (7.2million) live in Asia. They also claimed that worldwide, approximately 12 of every 1000 adults aged 15 to 49 are HIV infected. In subSaharan Africa about $9 \%$ of all adults in this age group (15-49years) are HIV infected.

According to Youth World Travel Organization (YWTO) (2002), by the end of December 1999, a cumulative total of 37, 298 cases of HIV/AIDS had been recorded in Ghana. Nearly 90\% of the cumulative AIDS cases from 1986-1999 in Ghana were between 15-49 years of age, with $63 \%$ of all reported cases being females. The female-to-male infection ratio however is gradually attaining parity, changing from 6:1 in 1987 to approximately 2:1 in 1998. The YWTO (2002) also stated that the peak ages for infection are 25-29years for females and 30-34years for males. The national prevalence rate of HIV has risen from $2.6 \%$ in 1994 to $4.6 \%$ in 1998. The National AIDS Control Programme (NACP) projects the average national prevalence rate to increase to $8.2 \%$ by 2009 and $9.5 \%$ by the year 2014 if the current trend continues. The YWTO (2002) observed that heterosexual transmission of HIV accounts for $75-80 \%$ of infection. Vertical transmission (from mother to child) accounts for $15 \%$ whilst transmission through blood accounts for $5 \%$.

\section{The Problem}

HIV/AIDS was first reported in 1986 in Ghana. Since then the disease has assumed alarming proportion in the country. This is due to a number of probable behavioural problems, namely: (i) the doubt people still have about the existence of HIV/AIDS, (ii) belief among some people that HIV/AIDS is a curse from God or from gods and offenders are the only people that can be infected, (iii) poverty and illiteracy which force the vulnerable group especially the young girls to fall victim to deceitful and greedy men as well as adventurous boys, (iv) possession of multiple sexual partners, (v) dislike for the use of condoms especially in the villages, (vi) unplanned sexual intercourse, and (vii) the use of blade and sharp edges used by other people. These imply that still people indulge in indiscriminate sex without protection. The end result is that some people especially innocent girls end up contracting HIV/AIDS. Another problem about HIV/AIDS in Ghana is that most often anybody who is ill and looks lean is considered to be suffering from HIV/AIDS. This means that, people with chronic illness are stigmatised and isolated whether they are suffering from AIDS or not. As a result, those who are actually infected go into hiding when they know their HIV/AIDS status and continue to infect more people. 
It is a common knowledge that HIV/AIDS infection rate is on the increase in the country (Antwi, 2003). For example, a survey result reported by Azu (2003) showed that the prevalence ranged from $8.5 \%$ in Koforidua to $1.6 \%$ in Nalerigu with a median coverage percentage of $3.4 \%$. The report went on to explain that Koforidua overtook Agormenya, which traditionally had the highest prevalence, in 2002. The report also indicated that the prevalence rate in the age group that raises concern is the 15-19 years brackets, an indication that new cases are emerging. This gives ample evidence that despite the campaigns on the disease in the media, the expected impact is not being made especially among the youth. What is more frightening is that places that were formerly considered to be free of HIV/AIDS infection are rather recording more cases of infection. No doubt the Ghana AIDS Commission with funding from some international organizations is making available colossal sums of money to Non-Governmental Organizations (NGOs) in the country to step up education on HIV/AIDS. Fortunately, some of such NGOs are in the forefront of advocacy on HIV/AIDS in the Agona district in the central Region of Ghana. However, for the NGOs to do effective work there is the need for them to be well informed of the level of awareness of the citizens especially the youth on the facts about HIV/AIDS. As a result, this study was designed to find out the knowledge of the youth especially Junior and Senior Secondary School students in the Agona District on HIV/AIDS as well as their attitudes towards sexual intercourse.

\section{Research questions}

- What is the level of awareness of Junior and Senior Secondary school students about the cause, mode of spread and prevention of HIV/AIDS?

- What are the attitudes of the Junior and Senior Secondary school students towards sexual intercourse?

- How do respondents view some issues pertaining to sexual intercourse?

- What are the views of respondents on condom use?

- What are the views of respondents on advertisements on HIV/AIDS?

\section{Objectives of the study}

The specific objectives of the study were to:

- to find out if some of the JSS and SSS students sampled have been having or have ever had sex

- find out the age at which those JSS and SSS students who have or have ever had sex first had it

- find out the attitudes of the students towards sexual intercourse,

- ascertain the level of awareness of respondents about the course, modes of spread, symptoms and preventive methods of HIV/AIDS,

- determine the awareness level of respondents on condom use and care for people living with HIV/AIDS (PLWHA)

- find out the views of students on advertisements on HIV/AIDS

\section{Methodology}

\section{Population and Sample}

The respondents were students from four Junior Secondary Schools (JSS) and two Senior Secondary Schools (SSS) in the Agona District. In all 70 boys and 70 girls were sampled from the Junior Secondary Schools (JSS) making a total of 140. Also, 41 boys and 41 girls were sampled from the Senior Secondary Schools making a total of 82. Therefore the total 
number of students sampled was 222. Only six schools were used because the study was a baseline study.

\section{Instrument and Sampling}

The main instrument used was a questionnaire. The questionnaire contained 20 items in all. Some of the items were closed-ended with dichotomous and multiple choice types. There were also open-end items

The study was carried out in April 2003. Students from each school were sampled randomly by allowing them to pick pieces of paper on which yes or no were written. Those who picked yes were given the questionnaire to fill whilst those who picked no were not given any questionnaire. The officials who administered the questionnaire made sure that respondents answered the questions and handed over at the spot. This ensured that all the questionnaires issued out were recovered. Attempts made to use interview method along with the questionnaire did not yield any good results because the students did not open up to give answers freely. This is because most of the officers who administered the questionnaire and conducted the interview were adults. Since, things pertaining to sex are not commonly spoken about with young people in Africa the children found it difficult talking about the issues raised. Hence, the interview results have not been included, because it was found not to be credible as views expressed when answering questions in the questionnaire. Items and their possible options in the questionnaire were explained to respondents in the common local language (Fante) that is spoken in the area before they answered the questions. This helped those students who were not very good in the English language to understand the questions before making any attempt of answering them. However, they were allowed to answer in English. This is because almost all the items had possible options.

\section{Data analysis}

The data for closed-ended items were analyzed by determining the frequency of each response for JSS and SSS students and the overall total frequency for each response was then calculated. Means and standard deviations were also calculated. The total percentages for the various responses were compared by using chi-square $\left(\mathrm{x}^{2}\right)$. For open-ended items descriptive analysis was done.

\section{Results}

From the results, $76.58 \%$ (170) of the students sampled were between $12-17$ years of age whilst the remaining $23.42 \%$ (52) were between $18-25$ years of age. From table 1, 27.03\% of the students had ever had sex. Out of these $9.91 \%$ were in Junior Secondary School (JSS) whilst $17.12 \%$ were in Senior Secondary School (SSS).. The results also show that $16.67 \%$ of respondents first had sex when they were $8-10$ years, $48.33 \%$ (29 respondents) between $11-15$ years and $35.0 \%$ ( 21 respondents) between 16-20years. Out of the 60 respondents who agreed to have ever had sex, $71.66 \%$ indicated that they did not use condoms and majority of them (46.67\%) were in SSS. Also, 28.33\% of the 60 students out of which $15 \%$ of them were in SSS claimed to be having sex still. Concerning sexual partners, $41.44 \%$ (92) stated that they did not have any whilst a total of 41.44 (92 students) claimed they had from one up to more than four sexual partners. However, 17.12\% (38 students) were silent on this (Table 2a). The results also showed that the boys were more sexually active (65\%, i.e. 39 boys) than the girls (35\%, i.e. 21 girls). The differences between the total percentage frequencies were very highly significant $(\mathrm{X} 2=104.44, \mathrm{P}<0.001)$. 
Table 1: Response to yes or no questions

\begin{tabular}{|c|c|c|c|c|c|c|c|c|c|c|c|c|}
\hline \multirow[b]{4}{*}{ Question } & \multicolumn{12}{|c|}{ Response } \\
\hline & \multicolumn{4}{|c|}{ JSS } & \multicolumn{4}{|c|}{ SSS } & \multicolumn{4}{|c|}{ Total } \\
\hline & \multicolumn{2}{|c|}{ Yes } & \multicolumn{2}{|c|}{ No } & \multicolumn{2}{|c|}{ Yes } & \multicolumn{2}{|c|}{ No } & \multicolumn{2}{|c|}{ Yes } & \multicolumn{2}{|c|}{ No } \\
\hline & $\mathbf{N}$ & $\%$ & $\mathbf{N}$ & $\%$ & $\mathbf{N}$ & $\%$ & $\mathbf{N}$ & $\%$ & $\mathbf{N}$ & $\%$ & $\mathbf{N}$ & $\%$ \\
\hline 1 Have ever had sex before & 22 & 10 & 60 & 27 & 38 & 17 & 102 & 46 & 60 & 27 & 162 & 73 \\
\hline 2. Still have sex & 8 & 13 & 14 & 23 & 9 & 15 & 29 & 48 & 17 & 28 & 43 & 72 \\
\hline 3. Use condom during sex & 8 & 13 & 14 & 23 & 15 & 25 & 28 & 47 & 23 & 38 & 43 & 77 \\
\hline 4. Ever heard of HIV/AIDS & 80 & 36 & 2 & 1 & 100 & 45 & 12 & 5 & 180 & 81 & 42 & 19 \\
\hline $\begin{array}{l}\text { 5. Believe in the existence of } \\
\text { HIV/AIDS }\end{array}$ & 80 & 36 & 2 & 1 & 100 & 45 & 12 & 5 & 180 & 81 & 42 & 19 \\
\hline $\begin{array}{l}6 \text {. Ever seen or heard any } \\
\text { advertisement on HIV/AIDS }\end{array}$ & 80 & 36 & 2 & 1 & 104 & 47 & 8 & 4 & 184 & 83 & 38 & 18 \\
\hline $\begin{array}{l}\text { 7. Any of the advertisements } \\
\text { made you understand the } \\
\text { cause, mode of spread, } \\
\text { symptoms and prevention of } \\
\text { HIV/AIDS }\end{array}$ & 76 & 34 & 6 & 3 & 100 & 45 & 12 & 5 & 176 & 79 & 46 & 21 \\
\hline $\begin{array}{l}\text { 8. Condoms readily available in } \\
\text { drug and chemical stores in } \\
\text { your locality }\end{array}$ & 70 & 31 & 12 & 5 & 92 & 41 & 48 & 22 & 162 & 73 & 60 & 27 \\
\hline $\begin{array}{l}\text { 9. Find it easy to enter drug or } \\
\text { chemical stores to buy } \\
\text { condoms }\end{array}$ & 20 & 9 & 62 & 28 & 26 & 12 & 114 & 51 & 46 & 21 & 176 & 79 \\
\hline
\end{tabular}

A high percentage of 41.44 respondents did not give any reason why one should have sex. However $30.63 \%$ (68 respondents) claimed that sexual intercourse is for satisfying one's sexual feelings. Also $10.36 \%$ ( 23 respondents) agreed that sex is for procreation (Table 2b). The differences between the total percentage frequencies were very highly significant $(\mathrm{X} 2=$ $76.10, \mathrm{P}<0.001)$. Concerning why condoms should be won during sexual intercourse, $62.61 \%(139$ respondents) stated that it is to prevent sexually transmitted diseases including HIV/AIDS, whilst $28.83 \%$ (64 respondents) observed that it is for preventing pregnancy (Table 3a). A further look at other responses showed that few other students (respondents) had misconceptions about condom use such as 'just to have a feel of its use', 'for fun', and' because others use it'. Here also, the differences between the total percentage responses were very highly significant $(\mathrm{X} 2=186.27, \mathrm{P}<0.001)$. 
Table 2 Responses to some questions on sex

\begin{tabular}{|c|c|c|c|c|c|c|}
\hline \multirow[b]{2}{*}{ Response } & \multicolumn{2}{|c|}{ JSS } & \multicolumn{2}{|c|}{ SSS } & \multicolumn{2}{|c|}{ Total } \\
\hline & Freq. & $\%$ & Freq. & $\%$ & Freq. & $\%$ \\
\hline \multicolumn{7}{|c|}{ a) How many sexual partners do you have? } \\
\hline i.None & 32 & 14.41 & 60 & 27.03 & 92 & 41.44 \\
\hline ii.One & 24 & 10.81 & 40 & 18.02 & 64 & 28.84 \\
\hline iii.Two & 12 & 5.41 & 7 & 3.15 & 19 & 8.55 \\
\hline iv.Three & 2 & 0.90 & 1 & 0.45 & 3 & 1.35 \\
\hline v.Four & 2 & 0.90 & 0 & 0 & 2 & 0.90 \\
\hline vi.More than four & 2 & 0.90 & 2 & 0.90 & 4 & 1.80 \\
\hline vii.No response & 8 & 3.60 & 30 & 13.51 & 38 & 17.12 \\
\hline Mean & & 5.28 & & 9.01 & & 14.29 \\
\hline $\begin{array}{l}\text { SD } \\
X^{2}=104.44 ; p<\end{array}$ & & 5.39 & & 10.65 & & $\mathbf{1 5 . 7 7}$ \\
\hline
\end{tabular}

b) Why should one have sex?

\begin{tabular}{lllllll}
\hline i.To satisfy one's feelings & 30 & 13.51 & 38 & 17.12 & 68 & 30.63 \\
ii.In order to get a baby & 16 & 7.21 & 7 & 3.15 & 23 & 10.36 \\
iii.Because others do it & 6 & 2.70 & 1 & 0.45 & 7 & 3.15 \\
iv.To be accepted by friends & 4 & 1.80 & 0 & 0 & 4 & 1.80 \\
v.For no particular reason & 16 & 7.21 & 12 & 5.41 & 28 & 12.62 \\
vi.No response & 10 & 4.50 & 82 & 36.94 & 92 & 41.44 \\
$\quad$ Mean & & $\mathbf{6 . 1 6}$ & & $\mathbf{1 0 . 5 1}$ & & $\mathbf{1 6 . 6 7}$ \\
SD & $\mathbf{4 . 2 6}$ & & $\mathbf{1 4 . 3 8}$ & & $\mathbf{1 5 . 9 3}$ \\
$\mathbf{X}^{\mathbf{2}=\mathbf{7 6 . 1 0} ; \mathbf{0 . 0 0 1}}$ & & & & & \\
\hline
\end{tabular}

In Table 1,72.97\% (162) of respondents indicated that condoms were readily available in drug and chemical stores in their localities. However, respondents found it difficult to buy the condoms (Table 3(b). The main reason given was due to fear of negative remarks from people (59.46\%, i.e. 132 respondents) and as a result of shyness (25.22\%, i.e. 56 respondents). From the results, $81.08 \%$ (180 respondents) agreed to have ever heard of HIV/AIDS and believe in its existence. Out of these, 45.05\% (100 respondents) were SSS students whilst 36.04\% (80 respondents) were JSS students. However, $6.31 \%$ (14 respondents) indicated that they had never heard of it and they did not believe in its existence, whilst $12.61 \%$ (28 respondents) seemed to have no idea at all (Table 1). On the cause of HIV/AIDS, 63.06\% (140 respondents; $36.94 \%$ for SSS and $26.13 \%$ for JSS) stated that it is caused by a germ or virus (Table 4a). However some of the respondents believed that HIV/AIDS is caused by curse from God or gods $(2.70 \%)$ or it is a punishment from God or gods $(4.50 \%)$ whereas $29.74 \%$ (66 respondents) seemed not to know the cause (Table 4a).

Results of how one can contract HIV/AIDS (Table 4b) showed that 22.97\% (ie 136) respondents attribute it to unprotected sex, $19.60 \%$, (i.e. 116 respondents) to blood transfusion with infected blood and the use of infected needles and syringes respectively, 15.20\% (90 respondents) and $12.84 \%$ (76 respondents) to the use of infected blade or Sharp edges, and from infected pregnant mother to child respectively. Some respondents have misconceptions such as 'through insect bite', and 'through embracing infected person'. The differences between the total frequencies were very highly significant $\left(X^{2}=44.77, \mathrm{P}<0.001\right)$. 
Table 3: Responses to some questions on condom use

\begin{tabular}{|c|c|c|c|c|c|c|}
\hline \multirow[b]{2}{*}{ Response } & \multicolumn{2}{|c|}{ JSS } & \multicolumn{2}{|c|}{ SSS } & \multicolumn{2}{|c|}{ Total } \\
\hline & Freq. & $\%$ & Freq. & $\%$ & Freq. & $\%$ \\
\hline
\end{tabular}

a) Why should one wear condom before having sexual intercourse?

\begin{tabular}{|c|c|c|c|c|c|c|}
\hline i.To prevent pregnancy & 20 & 9.01 & 44 & 19.32 & 64 & 28.83 \\
\hline $\begin{array}{l}\text { ii.Because condoms are being } \\
\text { advertised }\end{array}$ & 4 & 1.80 & 2 & 0.90 & 6 & 2.70 \\
\hline $\begin{array}{l}\text { iii.To prevent sexually } \\
\text { transmitted diseases } \\
\text { including HIV/AIDS }\end{array}$ & 50 & 22.52 & 89 & 40.09 & 139 & 62.61 \\
\hline iv.Just to have a feel of its use & 4 & 1.80 & 1 & 0.45 & 5 & 2.25 \\
\hline v.For fun & 2 & 0.90 & 3 & 1.35 & 5 & 2.25 \\
\hline vi.Because others use it & 2 & 0.90 & 1 & 0.45 & 3 & 1.35 \\
\hline Mean & & 6.16 & & 10.51 & & 16.67 \\
\hline SD & & 8.59 & & 16.37 & & 24.92 \\
\hline $\mathrm{X}^{2}=186.27 ; \mathrm{p}<0.001$ & & & & & & \\
\hline
\end{tabular}

b) Why do you find it difficult to buy condom?

\begin{tabular}{lrrrrrr}
\hline $\begin{array}{l}\text { i.Because people will call me } \\
\quad \text { a spoilt child }\end{array}$ & 46 & 20.72 & 86 & 38.74 & 132 & 59.46 \\
ii.Because of shyness & 27 & 12.16 & 29 & 13.06 & 56 & 25.22 \\
$\begin{array}{l}\text { iii.Because my community } \\
\quad \text { people do not like it }\end{array}$ & 2 & 0.90 & 8 & 3.60 & 10 & 4.50 \\
iv.To enjoy sex without it & & & & & & \\
v.Not necessary & 0 & 0 & 6 & 2.70 & 6 & 2.70 \\
$\quad$ Mean & 7 & 3.15 & 11 & 4.95 & 18 & 8.11 \\
SD & & $\mathbf{7 . 3 9}$ & & $\mathbf{1 2 . 6 1}$ & $\mathbf{2 0}$ \\
& & $\mathbf{8 . 8 8}$ & & $\mathbf{1 5 . 1 7}$ & $\mathbf{2 3 . 7 7}$ \\
\hline
\end{tabular}

Table 4a Responses on the cause and spread of HIV/AIDS

\begin{tabular}{|c|c|c|c|c|c|c|}
\hline \multirow[b]{2}{*}{ Response } & \multicolumn{2}{|c|}{ JSS } & \multicolumn{2}{|c|}{ SSS } & \multicolumn{2}{|c|}{ Total } \\
\hline & Freq. & $\%$ & Freq. & $\%$ & Freq. & $\%$ \\
\hline \multicolumn{7}{|l|}{ a) What causes HIV/AIDS? } \\
\hline i.Curse from God or gods & 6 & 2.70 & 0 & 0 & 6 & 2.70 \\
\hline $\begin{array}{l}\text { ii.As punishment from } \\
\text { god/gods for committing } \\
\sin \end{array}$ & 10 & 4.50 & 0 & 0 & 10 & 4.50 \\
\hline iii.A germ (virus) & 58 & 26.13 & 82 & 36.94 & 140 & 63.06 \\
\hline iv.I do not know & 8 & 3.60 & 58 & 26.13 & 66 & 29.74 \\
\hline Mean & & 9.21 & & 15.77 & & 25.0 \\
\hline SD & & 11.31 & & 18.73 & & 28.22 \\
\hline
\end{tabular}


Table 4b Responses on the cause and spread of HIV/AIDS

\begin{tabular}{|c|c|c|c|c|c|c|}
\hline \multirow[b]{2}{*}{ Response } & \multicolumn{2}{|c|}{ JSS } & \multicolumn{2}{|c|}{ SSS } & \multicolumn{2}{|c|}{ Total } \\
\hline & Freq. & $\%$ & Freq. & $\%$ & Freq. & $\%$ \\
\hline \multicolumn{7}{|l|}{ b) How is HIV/AIDS spread? } \\
\hline i.Through unprotected sex & 66 & 11.15 & 70 & 11.82 & 136 & 22.97 \\
\hline $\begin{array}{l}\text { ii.Through bathing with } \\
\text { infected persons }\end{array}$ & 0 & 0 & 0 & 0 & 0 & 0 \\
\hline $\begin{array}{l}\text { iii. Through transfusion of an } \\
\text { infected blood }\end{array}$ & 54 & 9.12 & 62 & 10.47 & 116 & 19.59 \\
\hline $\begin{array}{l}\text { iv. Through the use of } \\
\text { infected blade or sharp } \\
\text { edge }\end{array}$ & 36 & 6.08 & 54 & 9.12 & 90 & 15.20 \\
\hline $\begin{array}{l}\text { v.Through the use of } \\
\text { infected needle and } \\
\text { syringes }\end{array}$ & 34 & 5.74 & 82 & 13.85 & 116 & 19.60 \\
\hline vi.Through breast milk & 10 & 1.69 & 2 & 4.39 & 36 & 6.08 \\
\hline vii.Through insect bite & 0 & 0 & 10 & 1.69 & 10 & 1.69 \\
\hline $\begin{array}{l}\text { viii.From infected pregnant } \\
\text { mother to child }\end{array}$ & 36 & 6.08 & 40 & 6.76 & 76 & 12.84 \\
\hline $\begin{array}{l}\text { ix.Through embracing } \\
\text { infected person }\end{array}$ & 8 & 1.35 & 4 & 0.68 & 12 & 2.03 \\
\hline Mean & & 4.58 & & 6.16 & & 11.11 \\
\hline SD & & 4.04 & & 4.60 & & 8.83 \\
\hline$X^{2}=44.77 ; p<0.001$ & & & & & & \\
\hline
\end{tabular}

Table 5 Responses on symptoms and preventive measures of HIV/AIDS.

\begin{tabular}{|c|c|c|c|c|c|c|}
\hline \multirow{2}{*}{ Response } & \multicolumn{2}{|c|}{ JSS } & \multicolumn{2}{|c|}{ SSS } & \multicolumn{2}{|c|}{ Total } \\
\hline & Freq. & $\%$ & Freq. & $\%$ & Freq. & $\%$ \\
\hline \multicolumn{7}{|c|}{ a) What are the symptoms of HIV/AIDS? } \\
\hline $\begin{array}{l}\text { Frequent and prolonged } \\
\text { diarrhea }\end{array}$ & 20 & 4.42 & 42 & 9.29 & 62 & 13.72 \\
\hline $\begin{array}{l}\text { Frequent and prolonged } \\
\text { fever }\end{array}$ & 20 & 4.42 & 40 & 8.85 & 60 & 13.28 \\
\hline Loss of weight & 54 & 11.95 & 64 & 14.16 & 118 & 26.11 \\
\hline Loss of appetite & 18 & 3.98 & 34 & 7.52 & 52 & 11.50 \\
\hline Frequent sicknesses & 36 & 7.96 & 42 & 9.29 & 78 & 17.25 \\
\hline Forms of skin cancer & 10 & 2.21 & 18 & 3.98 & 28 & 6.19 \\
\hline $\begin{array}{l}\text { Frequent skin rashes } \\
\text { (shingles) }\end{array}$ & 18 & 3.98 & 36 & 7.96 & 54 & 11.94 \\
\hline Mean & & 5.56 & & 8.72 & & 14.28 \\
\hline $\mathrm{SD}$ & & 3.30 & & 3.02 & & 6.17 \\
\hline$X^{2}=16 ; p<0.05$ & & & & & & \\
\hline
\end{tabular}


Table 5b Responses on symptoms and preventive measures of HIV/AIDS.

\begin{tabular}{|c|c|c|c|c|c|c|}
\hline \multirow{2}{*}{ Response } & \multicolumn{2}{|c|}{ JSS } & \multicolumn{2}{|c|}{ SSS } & \multicolumn{2}{|c|}{ Total } \\
\hline & Freq. & $\%$ & Freq. & $\%$ & Freq. & $\%$ \\
\hline \multicolumn{7}{|c|}{ b) How can HIV/AIDS be prevented? } \\
\hline $\begin{array}{l}\text { Screening blood before } \\
\text { transfusion }\end{array}$ & 22 & 3.22 & 40 & 5.81 & 62 & 9.01 \\
\hline Use of condom & 58 & 8.43 & 56 & 8.14 & 114 & 16.57 \\
\hline $\begin{array}{l}\text { Avoidance of } \\
\text { indiscriminate sex }\end{array}$ & 42 & 6.10 & 52 & 7.56 & 94 & 13.66 \\
\hline $\begin{array}{l}\text { Not sharing blade and } \\
\text { tooth brushes }\end{array}$ & 46 & 6.69 & 54 & 7.85 & 100 & 14.54 \\
\hline Use of disposable needles & 10 & 1.45 & 34 & 4.94 & 44 & 6.39 \\
\hline $\begin{array}{l}\text { Infected couples avoid } \\
\text { having children }\end{array}$ & 20 & 2.91 & 40 & 5.81 & 60 & 8.72 \\
\hline Abstinence from sex & 54 & 7.85 & 64 & 9.30 & 118 & 17.15 \\
\hline $\begin{array}{l}\text { Staying faithful to one } \\
\text { sexual partner }\end{array}$ & 42 & 6.10 & 54 & 7.85 & 96 & 13.95 \\
\hline Mean & & 5.34 & & 7.16 & & 12.50 \\
\hline SD & & 2.52 & & 1.47 & & 3.96 \\
\hline$X^{2}=8.56 ; p>0.05$ & & & & & & \\
\hline
\end{tabular}

Table 6: Responses to how to relate with HIV/AIDS infected persons

What things can you do with HIV/AIDS infected persons without getting infected?

$$
\text { JSS SSS Total }
$$

\begin{tabular}{|c|c|c|c|c|c|c|}
\hline Response & Freq. & $\%$ & Freq. & $\%$ & Freq. & $\%$ \\
\hline i.By eating with them & 52 & 8.07 & 76 & 11.80 & 128 & 19.87 \\
\hline $\begin{array}{l}\text { ii.By sleeping on the same } \\
\text { bed with them }\end{array}$ & 42 & 6.53 & 62 & 9.62 & 104 & 16.14 \\
\hline iii.By bathing with them & 36 & 5.59 & 58 & 9.01 & 94 & 14.60 \\
\hline iv.By embracing them & 38 & 5.90 & 60 & 9.32 & 98 & 15.22 \\
\hline $\begin{array}{l}\text { v.By using the same blade } \\
\text { with them }\end{array}$ & 0 & 0 & 0 & 0 & 0 & 0 \\
\hline $\begin{array}{l}\text { vi.By using the same needle } \\
\text { with them }\end{array}$ & 4 & 0.62 & 0 & 0 & 4 & 0.62 \\
\hline vii.By having sex with them & 14 & 2.17 & 0 & 0 & 14 & 2.17 \\
\hline $\begin{array}{l}\text { viii.Exchange blood with } \\
\text { them through blood } \\
\text { covenant }\end{array}$ & 6 & 0.93 & 0 & 0 & 6 & 0.93 \\
\hline $\begin{array}{l}\text { ix.By sitting with them in } \\
\text { the same vehicle }\end{array}$ & 38 & 5.90 & 64 & 9.93 & 102 & 15.83 \\
\hline $\begin{array}{l}\text { x.By allowing them to enter } \\
\text { our shops }\end{array}$ & 30 & 4.66 & 64 & 9.93 & 94 & 14.59 \\
\hline Mean & & 4.01 & & 5.96 & & 10.0 \\
\hline SD & & 2.83 & & 5.18 & & 7.96 \\
\hline$X^{2}=57.01 ; p<0.001$ & & & & & & \\
\hline
\end{tabular}



Hordzi, W. H. K.Hordzi, W. H. K.

Table 7: Respondents views about advertisements related to HIV/AIDS

\begin{tabular}{|c|c|c|c|c|c|c|}
\hline \multirow[b]{2}{*}{ Response } & \multicolumn{2}{|c|}{ JSS } & \multicolumn{2}{|c|}{ SSS } & \multicolumn{2}{|c|}{ Total } \\
\hline & Freq. & $\%$ & Freq. & $\%$ & Freq. & $\%$ \\
\hline \multicolumn{7}{|c|}{ a) Types of HIV/AIDS advertisements respondents aware of } \\
\hline i.Car stickers & 14 & 2.67 & 38 & 7.25 & 52 & 9.92 \\
\hline ii.T-shirts & 20 & 3.82 & 46 & 8.78 & 66 & 12.60 \\
\hline iii.Sign boards & 22 & 4.20 & 16 & 3.05 & 38 & 7.26 \\
\hline iv.Radio talks & 56 & 10.69 & 64 & 12.21 & 120 & 22.90 \\
\hline v.Television shows & 72 & 13.74 & 74 & 14.12 & 146 & 27.86 \\
\hline $\begin{array}{l}\text { vi.HIV/AIDS education } \\
\text { campaigns }\end{array}$ & 30 & 5.73 & 72 & 13.74 & 102 & 19.47 \\
\hline Mean & & 6.81 & & 9.8 & & 16.67 \\
\hline $\begin{array}{l}\text { SD } \\
X^{2}=20.97 ; p<0.001\end{array}$ & & 4.41 & & 4.31 & & 8.03 \\
\hline \multicolumn{7}{|c|}{ b) Impression of condom advertisement } \\
\hline $\begin{array}{l}\text { i.To have sex anytime by } \\
\text { wearing it }\end{array}$ & 15 & 6.76 & 17 & 7.66 & 32 & 14.42 \\
\hline $\begin{array}{l}\text { ii.Condom can protect } \\
\text { against sexually } \\
\text { transmitted diseases } \\
\text { including HIV/AIDS }\end{array}$ & 50 & 22.52 & 70 & 31.53 & 120 & 54.05 \\
\hline $\begin{array}{l}\text { iii.Sex can be enjoyed } \\
\text { irrespective of age by } \\
\text { wearing condom }\end{array}$ & 2 & 0.90 & 8 & 3.60 & 10 & 4.50 \\
\hline $\begin{array}{l}\text { iv.Couples can use } \\
\text { condom to prevent } \\
\text { unplanned pregnancy }\end{array}$ & 15 & 6.76 & 45 & 20.27 & 60 & 27.03 \\
\hline Mean & & 9.24 & & 15.77 & & 25.0 \\
\hline SD & & 9.28 & & 12.68 & & 21.14 \\
\hline
\end{tabular}

The results in Table 6 show that all the respondents know that one needs not use the same blade with HIV infected person and a very small number of them also know that one needs not exchange blood with them $(0.93 \%)$. The differences between the total percentages $\left(X^{2}=\right.$ 57.01, $\mathrm{P}<0.001)$ were very highly significant. The results show that the SSS students are better informed of how to relate well with PLWHA than JSS students. Television shows happen to be the most popular means of advertisement on HIV/AIDS with respondents (27.86\%), followed by radio talks (22.90\%, i.e. 120 respondents) and HIV/AIDS education campaigns $(19.47 \%$ i.e. 102 respondents) (Table $7 \mathrm{a})$. The differences between the total responses $\left(X^{2}=20.97, P<0.001\right)$ were very highly significant. In Table 7(b), 54.05\% (120 respondents) observed that condom prevents STDs including HIV/AIDS. However, only $28.83 \%$ (64 respondents) were aware that couples could use condoms to prevent unplanned pregnancies. The other two answers are negative but some respondents agreed to them (Table $7 b)$.

\section{Discussions}

From the results, $76.58 \%$ (170) of the students sampled were between 12-17 years of age whilst the remaining $23.42 \%$ (52) were between $18-25$ years of age. Monono (2000) observed that the age group most infected by HIV/AIDS is $15-44$ years. In this study it is clear from 
Table 1 that $27.03 \%$ of the students had ever had sex before. Out of these $9.91 \%$ were in Junior Secondary School (JSS) whilst $17.12 \%$ were in Senior Secondary School (SSS). Kaaya, Fisher, Mbwambo, Schaaima, Aaro, and Klepp (2002) claimed that sexual behaviour of students in Sub-Saharan Africa is characterized by high prevalence rate of sexual intercourse. Eaton, Fisher and Aaro, (2003) stated that at least 50\% of young people in South Africa are sexually active at the age of 16 and probably $8 \%$ are by the age of 20 . In this research $16.67 \%$ of respondents first had sex when they were 8-10 years, 48.33\% (29 respondents) between $11-15$ years and $35.0 \%$ between 16-20years.

This finding is worrying because at such tender ages the children are not biologically, socially or psychologically ready for sex. Out of the 60 respondents who agreed to have ever had sex before, $71.66 \%$ indicated that they did not use condoms and majority of them $(46.67 \%)$ were in SSS. This is in line with findings of Eaton et al (2003) who observed that majority of sexually active youth in South Africa irregularly use condom, if at all. Also, $28.33 \%$ of the 60 students out of which $15 \%$ of them were in SSS claimed to be having sex still. Eaton et al (2003) further stated that majority of school going adolescents reported in a research had one or more sexual partners whilst others had more than four. In this study, the fact that $41.44 \%$ (92 students) agreed to have sexual partners means that they used to have sex. Naturally, it is not surprising that the boys were more sexually active than the girls because boys are generally more adventurous than girls. It may also be so because in Africa for that matter Ghana it is the males who propose love but not the females.

Peltzer and Seoka (2004) in a research results from South Africa stated that the major reason given by people for not using male condoms with sex partners included 'don't like them', 'don't think of it', 'don't think it was necessary,' 'not available', and 'partner objected'. Siegel, Di Clemente, Durbin, Kirasnovsky and Saliba (1995) stated that significant gaps in adolescents' knowledge of HIV have been consistently identified among junior high school students especially regarding misconceptions about causal transmission and prevention. At the same time these youth have a high prevalence of behaviours that put them at risk for HIV infection including earlier sexual onset, infrequent condom use, and multiple sexual partners. In this study, concerning why condoms should be won during sexual intercourse, $62.61 \%(139$ respondents) stated that it is to prevent sexually transmitted disease including HIV/AIDS, whilst $28.83 \%$ (64 respondents) observed that it is for preventing pregnancy. The response to the two answers put together is very encouraging (Table 3a) because these are positive answers. A further look at other responses showed that few other students (respondents) had misconceptions about condom use such as 'just to have a feel of its use', 'for fun', and' because others use it'. This suggests that more education needs to be carried out about condom use

Peltzer and Seoka (2004) asserted that there is the need to increase the availability of condoms in rural areas of Africa and social marketing strategies can be used to increase the acceptability of condom use. Campbell and Mzaidume (2002) also postulated that providing information about HIV/AIDS and promotion of local condom availability could have optimal impact on the spread of HIV/AIDS. In this study, the results showed that though condoms were readily available in some localities, respondents found it difficult to buy them. This is because only $20.72 \%$ (46 respondents) found it easy walking into drug and chemical stores to buy them (condoms)(Table1) This is mainly due to fear of negative remarks from people and as a result of shyness. These points suggest that if HIV infection rate among the youth can be reduced then the promiscuous ones need to be encouraged to use the condom. One way of doing that is to remove all the stigma attached to the purchase and use of the condom. HIV prevalence rate in Africa is largely due to risky sexual behaviours that may in part be due to lack of knowledge (Siegel et al, 1995). In this study $81.08 \%$ (180 respondents) agreed to have ever heard of HIV/AIDS. Those respondents who indicated that they had never heard of HIV/AIDS might be pretending or had genuine case. However, the fact that some of them said that they did not believe in the existence of HIV/AIDS is not surprising because it is a common statement from some adults and their wards could also pick up the same idea. Such 
respondents probably need to be brought face to face with someone suffering from HIV/AIDS so that they can hear the story from the horse's own mouth.

On the cause of HIV/AIDS also, it can be said that though a high percentage of respondents $(63.06 \%)$ gave the right answer, there is the need to take the case of the few having misconceptions and those who do not know seriously. This is because ignorance or misconception can lead one to have false hope and indulge in unsafe sex that can lead to the contraction of the disease. Nyido (2005) stated that antiquated beliefs are one of the main reasons why HIV-1 is on the increase in Sub-Saharan Africa. In this study results of how one can get HIV/AIDS (Table 4b) showed that $22.97 \%$ (ie 136) respondents attribute it to unprotected sex, $19.60 \%$, (i.e. 116 respondents) for blood transfusion with infected blood and the use of infected needles and syringes respectively, $15.20 \%$ (90 respondents) and $12.84 \%$ (76 respondents) for use of infected blade or Sharp edges, and from infected pregnant mother to child respectively. Some respondents have misconceptions such as 'through insect bite', and 'through embracing infected person'. Peltzer and Seoka (2004) in similar research in South Africa claimed that some respondents stated that HIV can be spread through mosquito bites and sharing eating utensils, which needs to be addressed through clear educational messages and socio-cultural influence. O. C. P. L. (2003) also observed that biting insects such as mosquitoes or bedbugs do not spread HIV. However, HIV can infect anyone who practices risky behaviours such as sharing drug needle or syringes, having unprotected sexual intercourse with an infected person and or someone whose HIV status is not known, transmission of infected blood and the use of infected sharp edges. It is however refreshing to note that all the respondents were aware that eating with an infected person could not transmit the disease.

Some of the common symptoms of opportunistic infections in people with AIDS are: protracted coughing, and shortness of breath, seizures and lack of coordination, difficult or painful swallowing, mental symptoms such as confusion and forgetfulness, severe and persistent diarrhea, fever, vision loss, nausea, abdominal cramps, and vomiting, weight loss and external fatigue, severe headaches and coma, cancers, especially those caused by viruses such as kaposis sarcoma and cervical cancer, or cancer of the immune system known as lymphomas (O.C.P.L, 2003). Of all the known symptoms presented to respondents (Table 5a), loss of weight appeared to be the most popular (26.16\% (118 respondents). All the other responses are very close except forms of skin cancer, which scored below $10 \%$. However, the percentages in the results show that majority of the respondents do not know that the other symptoms can present themselves in HIV infected persons. This calls for intensification of education on all the symptoms of HIV/AIDS but not only on weight loss. If this is not done those who appear to be emaciated from any other pathological or natural means can be considered as suffering from HIV/AIDS and be stigmatized.

Peltzer and Seoka (2004) stated that reduction of sexual partners may be more feasible method of preventing HIV infection than condom use. Shisana and Simbayi (2002) observed that condom use, adopting particular prevention strategies and faithfulness can actually help to reduce HIV infection. In this study apart from screening blood before transfusion, use of disposable needles, and the need for infected couples not having children, all the other known preventive measures stated recorded between $13.95 \%$ and $17.15 \%$ response. The most popular preventive measure that the students knew was abstinence $(17.15 \%)$ though the percentage appears to be low (Table 5b). This is not however surprising because most of the advertisements on HIV/AIDS emphasize abstinence, condom use and staying faithful to ones sexual partner. However, it will do society a lot of good if all the possible preventive measures such as screening blood before transfusion, avoidance of unprotected sex, avoidance of sharing blades, tooth brushes and sharp edges as well as infected persons avoiding having children can be equally highlighted during various campaigns on HIV/AIDS. This will enable us to have a holistic approach to the awareness creation on the disease and prevent our youth from doing things that predispose them to infection. 
Although HIV has been found in the saliva by researchers, there is no evidence that the virus is spread by contact with saliva. There is also no evidence that HIV is spread through sweat, tears, urine or faeces. The virus is not spread through casual contact such as the sharing of food utensils, towels and bedding, swimming pools, telephones or toilet seats (O. C. P. L. 2003). The results in Table 6 show that all the respondents know that one needs not use the same blade with HIV infected person and a very large number also know that one needs not exchange blood with them $(0.93 \%)$. The results also showed that respondents have fair idea about how to live with HIV infected persons without contracting the disease. The results show that the SSS students are better informed about how to relate well with PLWHA than JSS students. This may be due to the fact that the SSS students are more matured than the JSS students.

In South Africa some of the media used in carrying HIV/AIDS messages are television, magazines as well as friends (Kaya and Mabetoa, 1997); HIV/AIDS campaigns, billboards and newspaper advertisements (Harrison, Smit and Myer 2000). In this study television shows happen to be the most popular with respondents $(27.86 \%)$, followed by radio talks $(22.90 \%$, i.e 120 respondents) and HIV/AIDS education campaigns (19.47\% i.e. 102 respondents) (Table 7a). This suggests that if messages are well packaged on the television and radios, more people may understand the necessary facts of HIV/AIDS. However, it will be difficult to achieve $100 \%$ coverage because not every family can afford television or radio. It is believed that more impact can be made if more people are involved in the campaign on the disease. This can take the form of peer education, drama and poem recitals.

In Table 7(b), 54.05\% (120 respondents) observed that condom prevents STDs including HIV/AIDS. However, only $28.83 \%$ (64 respondents) were aware that couples could use condoms to prevent unplanned pregnancies. The other two answers are negative but some respondents agreed to them (Table 7b). This shows that some students and some youth hold the view that because of condom, sex can be enjoyed anytime or by anybody irrespective of age. These two notions are sources of disaster because they influence the youth to become promiscuous and as a consequence contract HIV/AIDS if they are not properly used.

\section{Conclusions and Recommendation}

From the results, it is clear that JSS and SSS students are sexually active in the Agona district and some even begin as early as 8years of age. This situation may not be peculiar to Agona district alone but may be occurring in other districts in the country and other African countries. As a result, it is hereby recommended to NGOs to focus their education more on the consequences of early sex. Also, school and educational authorities need to put in place effective guidance and counseling procedures to dissuade students from early sex. It may also be of help to society if HIV/AIDS can be included in the JSS and SSS curriculum as a subject on its own. Parents are also to be encouraged to take the first step of introducing sex education at home before the child enters school.

The fact that some respondents seemed not to know the actual cause of HIV/AIDS either deliberately or genuinely then there is the need to device appropriate messages on HIV/AIDS to make majority of the youth aware of the causative agent of the disease. Also, since some respondents claimed that they do not believe in the existence of the disease, frantic efforts should be made to use real HIV/AIDS cases in educating the youth. In doing so care should be taken not to abuse the rights of the people to be used. Similarly, the results showed that though most of the respondents had good ideas about the various modes of spread, symptoms and preventive measures of the disease, a sizeable number of them actually had faint ideas or had misconceptions about some of these things. Hence, it is therefore recommended that more peer educators be trained to undertake one-on-one or small group discussions on such subjects.

On the preventive measures, though abstinence should be stressed, any other relevant preventive measures should be given high attention in the campaign against HIV/AIDS. 
Since some of the youth will have sexual intercourse no matter the level of awareness created, it will be advisable to teach the use of condoms so that such young people can make the attempt of protecting themselves against HIV/AID. Similarly, there is the need to stress on the consequences of blood covenants since some young people consumed by passion adopt this as a way of showing total allegiance to their supposed lovers. Since not every home can afford a TV set or radio set, more group discussions and peer education should be adopted especially in the rural set ups to combat the HIV/AIDS menace. However, well packaged and simple to understand messages on the disease can be placed on the TV and radio for a segment of the people to benefit from.It is also recommended that school and educational authorities fully involve their students in the educational activities aimed at eradicating HIV/AIDS in the society.

\section{References}

Alhassan, B. A. (2001): The impact of HIV/AIDS on Development in Africa. Journal of Educational Development, IEDE, volume 1(1):

Antwi, G. (2003): HIV/AIDS cases on the rise in Kwahu, $26^{\text {th }}$ June Edition of Ghanaian Chronicle, Posted to the Internet

Azu, V. (2003): HIV/AIDS figures are scaring, $12^{\text {th }}$ July Edition of the Mirror, P.3.

Campbell, C and Mzaidume, Y.( 2002): How can HIV be prevented in South Africa? A Social Perspective. British Medical Journal 324: 229 - 232.

Eaton, L, Fisher A.J, and Aaro, L. E. (2003): Unsafe Sexual Behaviour in South African Youth. Social Science and Medicine56 (1):149 - 165.

Harrison, A; Smit J.A; and Myer, L. (2000): Prevention of HIV/AIDS in South Africa: a review of behaviour change interventions, evidence and options for the future. South African Journal of Science 96: 286 - 290.

Kaaya S. F., Fisher A. J, Mbwambo J. K., Schaaima, H., Aaro, L.E, and Klepp, K. I. (2002): A Review of studies of sexual behaviour of students in Sub Saharan Africa. Scandinavian Journal of Public Health 30:48 - 160.

Kaya, H. Q, and Mabetoa, P. (1997): Knowledge and attitude towards sexuality among Black Youth in South Africa. Education and Society 15(1): 81 - 87.

Monono, E. (2000): AIDS, responsibility and the future. Keynote address to graduates, $4^{\text {th }}$ November, University of Bruce, Cameroon.

Nyindo, M. (2005): Complementary Factors Contributing To The Rapid Spread Of HIV-1 In Sub-Saharan Africa: A Review. East African Medical Journal, 182 (1: 40-45

Office of Communications and Public Liaison (O.C.P.L.) (2003): HIV Infection and AIDS. An overview. The Internet

Peltzer, K. and Seoka, P. (2004): Evaluation of HIV/AIDS prevention intervention messages on a rural sample of South African youth's knowledge, attitudes, beliefs and behaviours over a period of 15 months. Journal of Child and Adolescent Mental Health 16(2: $93-102$.

Shisana, O. and Simbayi, L. (2002): South African National HIV Prevalence, Behavioural Risks and Mass Media Household Survey 2002. Human Sciences Research Council, Cape Town, South Africa

Siegel, D; DiClemente, R; Durbin M; Kirasnovsky F. and Saliba, P. (1995): Change in Junior High School Students' AIDS - related knowledge, misconceptions, attitudes and HIV - Preventive behaviours: effects of a school-based intervention. AIDS Education and Prevention 7(6): 534 - 543. 
African Journal of Educational Studies in Mathematics and Sciences Vol. 4, 2006

UNAIDS (2002): AIDS Epidemic update, December 2002. Youth World Travel Organization (Y.W.T.O) (2002): HIV/AIDS in Ghana. The Internet 